Jurnal IImiah Iqra'

2541-2108 [Online] 1693-5705 [Print]

Tersedia online di: http://journal.iain-manado.ac.id/index.php/JII

\title{
Pendidikan Anak Pada Masyarakat Muslim Transmigran Di Desa Huwongo Paguyaman Kabupaten Boalemo Provinsi Gorontalo
}

\author{
Sulfa Potiua \\ IAIN Manado, Manado, Indonesia \\ sulfapotiua10@gmail.com
}

\begin{abstract}
Abstrak
Tulisan ini bertujuan untuk mengetahui lebih dalam tentang Pendidikan formal maupun non formal pada anak masyarakat muslim Transmigran di desa Huwongo Paguyaman Kabupaten Boalemo Provinsi Gorontalo.

Pada umumnya berbagai bentuk pelaksanaan pendidikan telah nampak pada masyarakat Transmigran di Desa Huwongo ini. Hal ini bisa dibuktikan dengan tidak seorang anakpun dari masyarakat Transmigran ini yang tidak mengenyam pendidikan. Hal ini disebabkan oleh dorongan dan kemauan orang tua itu sendiri karena bagi mereka apapun keadaannya anak-anak tetap wajib belajar terutama di sekolah formal, hal ini juga dibuktikan dengan prestasi anak - anak masyarakat Transmigran desa Huwongo sangat baik sekali, ini terlihat dari prestasi di setiap penyerahan raport di tiap semester di sekolah selalu yang menjadi unggul prestasi siswa adalah anak-anak dari masyarakat Transmigran desa Huwongo dibandingkan dengan anak-anak masyarakat lokal, ini karena dorongan dan motivasi dari orang tua masing - masing masyarakat Transmigran desa Huwongo.

Sebagai kendala Pendidikan formal karena belum ada sekolah formal khusus masyarakat Transmigran akan tetapi itu tidak menyulut niat orang tua untuk menyekolahkan anak-anak mereka, bahkan SMP dan SMA itu sangat jauh dari tempat tinggal akan tetapi bukan jadi penghalang untuk melanjutkan anak-anak mereka dalam sekolah formal.

Masalah Pendidikan non formal anak pada masyarakat muslim Transmigran Desa Huwongo ini tidak berbanding lurus dengan kemajuan Pendidikan formalnya. Hal ini dibuktikan dengan pengamatan penulis maupun hasil wawancara dengan masyaakat maupun pengakuan dari pengurus bahwa banyak kendala tentang Pendidikan non formal ini, yang disebabkan diantaranya adalah kurangnya dorongan dari orang tua dan juga kurang kesadaran dari anak-anak itu sendiri.
\end{abstract}

Kata kunci: Pendidikan; Transmigran 


\begin{abstract}
Children's Education in Transmigrant Muslim Communities in Huwongo Paguyaman Village, Boalemo Regency, Gorontalo. This paper aims to find out more about formal and non-formal education in the children of Muslim transmigrants in the village of Huwongo Paguyaman, Boalemo Regency, Gorontalo.

In general, various forms of implementation of education have been seen in the Transmigrant community in Huwongo Village. This can be proven by not having a child from this Transmigrant community who has not received an education. This is due to the encouragement and willingness of the parents themselves because for them, whatever the circumstances, children are still obliged to study, especially in formal schools, this is also evidenced by the achievements of the children of the Transmigrant community in Huwongo village very well, this can be seen from the achievements in every the delivery of report cards in each semester at school is always the superior student achievement is the children of the Transmigrant community of Huwongo village compared to the children of the local community, this is due to the encouragement and motivation of their parents - each of the Transmigrants of Huwongo village.

As an obstacle to formal education because there is no formal school specifically for the transmigrant community but it does not spark the intention of parents to send their children to school, even junior high and high school are very far from where they live but it is not a barrier to continue their children in school formal.

The problem of children's non-formal education in the Muslim community of Transmigrants in Huwongo Village is not directly proportional to the progress of their formal education. This evidenced by the author's observations and the results of interviews with the community as well as the acknowledgment of the management that there are many obstacles regarding this non-formal education, which is caused by the lack of encouragement from the parents and also lack of awareness of the children themselves.
\end{abstract}

Keywords: Education; Transmigrant

\title{
Pendahuluan
}

Pendidikan adalah investasi sumber daya manusia jangka panjang yang mempunyai nilai strategis bagi kelangsungan peradaban manusia di dunia. Hampir semua negara menempatkan variabel pendidikan sebagai suatu yang penting dan utama dalam konteks pembangunan bangsa dan negara. Begitu juga Indonesia menempatkan pendidikan sebagai suatu yang utama (Firmadani, 2017). Hal ini dapat dilihat pada isi Pembukaan Undang-Undang Dasar (UUD) Negara Republik Indonesia Tahun 1945 alinea IV (empat) yang menegaskan bahwa salah satu tujuan Nasional Bangsa Indonesia adalah mencerdaskan kehidupan bangsa (Kristiawan, 2017). 
Masyarakat sebagaimana diketahui merupakan bagian dari komponen pendidikan yang turut serta memikul tanggung jawab pendidikan dan pengaruhnya dalam memberi arah terhadap pendidikan anak sangatlah besar, terutama para pemimpin masyarakat atau penguasa, di pundak mereka terpikul keikutsertaan membimbing pertumbuhan dan perkembangan terhadap penyelenggaraan pendidikan khususnya pada lembaga pendidikan (Daeng Pawero, 2018).

Masyarakat yang dimaksudkan disini adalah keluarga dimana keluarga tersebut sebagai pranata sosial yang utama, tidak disangkal lagi mempunyai arti yang sangat penting dan strategis dalam mengisi dan membekali nilai-nilai kehidupan yang dibutuhkan oleh anak yang tengah mengisi makna kehidupan (Mahmud \& Dkk, 2013). Keluarga jangan hanya dimaknai secara fisik yang terdiri dari bapak, ibu, dan anak, karena keluarga mempunyai nilai fungsional dalam membentuk pribadi anak guna mencapai kedewasaan dan kesempurnaan hidup.

Keluarga adalah salah satu mata rantai kehidupan yang sangat esensial dalam perjalanan hidup anak. Rumahku surgaku (baiti jannati) adalah ungkapan yang sangat tepat untuk mengungkapkan sebuah bangunan rumah yang ideal. Membangun rumah yang memberikan kenyamanan, kesejukan, dan keteduhan hati setiap penghuninya serta keridhoan Allah swt. adalah tanggung jawab orang tua. Setiap orang tua tentu menginginkan yang terbaik bagi anak-anaknya. Usaha untuk menjadikan anak yang lebih baik salah satu faktor pembentuknya adalah suasana keluarga yang kondusif serta dapat mendukung perkembangan anak.

\section{Kajian Teori}

\section{Peran Orang Tua}

Kegiatan apapun di rumah tidak bisa dilepaspisahkan dari peran guru pertama dan paling utama yaitu orang tua. Agar maksimal dan berhasil dalam mendidik anak para orang tua harus mengetahui karakter, pendekatan, dan metode dalam mendidik anak (Daradjat, 2018).

Agama Islam menaruh perhatian yang sangat besar dalam proses mengasuh dan mendidik anak. Ajaran Islam dalam mengasuh dan mendidik anak sangat lengkap dan menyeluruh. Proses mengasuh dan mendidik anak dimulai jauh sebelum anak itu lahir. Terutama persiapan diri dengan memperbaiki agama dan akhlaknya, karena Allah swt. mengisyaratkan bahwa wanita yang baik hanya untuk laki-laki yang baik dan laiki-laki yang baik hanya untuk wanita yang baik pula (Farihah 
\& Nurani, 2017). Oleh karena itu, apabila seseorang menginginkan pasangan yang baik maka terlebih dahulu ia harus memperbaiki diri dan menjadi orang yang baik, terutama agama dan akhlaknya. Proses selanjutnya dilanjutkan ketika calon suami memilih calon istrinya karena istri atau calon ibu inilah yang akan manjadi ibu bagi anak-anaknya sekaligus dialah yang akan menjadi pengasuh dan pendidik yang pertama bagi anaknya.

Ajaran kepemimpinan Ki Hajar Dewantara dengan semboyan Ing Ngarso Sung Tulodo, Ing Madyo Mangun Karso, Tut Wuri Handayani secara tegas memberikan pelajaran agar seorang pemimpin, guru, dan orang tua memiliki tiga sifat yang terkandung dalam semboyan tersebut. Makna Ing Ngarso Sung Tulado adalah seorang pemimpin, guru, dan orang tua harus mampu memberikan suri tauladan. Sebagai pemimpin, guru, dan orang tua harus memiliki sikap dan prilaku yang baik di segala langkah dan tindakan agar dapat menjadi panutan bagi bawahan dan anak didiknya (A. M. V. D. Pawero, 2017). Makna Ing Madyo Mangun Karso adalah seorang figur pemimpin, guru, dan orang tua yang baik adalah yang tidak hanya dapat menjadi suri tauladan atau panutan, tetapi juga harus mempu menggugah semangat dan memberi motivasi serta dorongan moral. Semboyan Tut Wuri Handayani artinya dari belakang seorang pendidik harus bisa memberi dorongan dan arahan (Yamin, 2010).

Nur Hidayah dalam hasil penelitiannya yang di kutip oleh Mohammad Shochib mengindikasikan bahwa pola asuh dan sikap orang tua yang demokratis menjadikan adanya komunikasi yang dialogis antara anak dan orang tua dan adanya kehangatan yang membaut anak remaja merasa diterima oleh orang tua sehingga ada pertautan perasaan. Oleh karena itu, anak remaja yang merasa diterima oleh orang tua mungkin meraka untuk memahami, menerima, dan mengintegrasikan pesan nilai moral yang diupayakan untuk diapresiasikan berdasarkan kata hati (Shochib, 2001).

Fakta di atas menunjukkan bahwa interaksi dalam pendidikan keluarga harus dibangun dengan pendekatan demokratis sehingga akan terjalin komunikasi yang dialogis antara anak dan orang tua. Walaupun hakekat pembentukan kepribadian anak terjadi dalam masa yang sangat panjang, yaitu sejak ia dalam kandungan, kehidupan sehari-hari bersama orang tua dan sanak saudara, sekolah, dan masyarakat. Idealnya semuanya harus terhindar dari tindak otoritatif dan penindasan psikologis. 


\section{Masyarakat Transmigran}

Indonesia merupakan negara archipelago (kepulauan) yang kaya akan natural resource (sumber daya alam) yang belum tergali secara keseluruhan, sedangkan sebagian besar penduduk masih terkonsentrasi di pulau Jawa, maka program Transmigrasi adalah salah satu program yang tepat untuk mencapai kepada penyebaran penduduk sekaligus pencapaian kesejahteraan (Suparno, 2007). Transmigrasi merupakan program pemerintah dengan upaya pemindahan penduduk dari satu daerah ke daerah lain yang masih dalam wilayah negara Republik Indonesia (Redaksi Ensiklopedi Nasional, 1990). Harapannya adalah para transmigran mampu mengeksplorasi sumber daya alam dimana mereka ditempatkan pada daerah (hunian/ lahan baru) sebagai tempat tinggalnya.

Pada dasarnya Transmigrasi tidak hanya upaya pemerintah untuk mengurangi tingkat kepadatan penduduk semata, melainkan juga upaya pemerintah dalam mengentaskan kemiskinan yang selanjutnya bisa menciptakan human resources (sumber daya manusia) dengan tujuan agar dapat memajukan Bangsa Indonesia (Sedarmayanti, 2011).

Sesuai pengamatan peneliti Desa Huwongo Paguyaman merupakan penduduk trasmigran yang berhasil. Hal tersebut dapat dilihat dari peningkatan tarap hidup dan terpenuhinya kebutuhan primer dan sekunder. Pertumbuhan dan perkembangan pembangunan di Daerah Transmigran di Desa Huwongo Paguyaman dari berbagai aspek mengalami peningkatan yang signifikan. Hal ini dapat dilihat dari pertumbuhan dan perkembangan pembangunan tempat-tempat usaha, pembangunan rumah dan meningkatnya daya beli masyarakat terhadap kebutuhankebutuhan yang sifatnya sekunder. Didukung dengan pembangunan jalan sebagai akses, yang menghubungkan daerah Transmigran dengan pusat-pusat ekonomi, masuknya investor berskala besar dan bertarap internasional, serta rencana di bentuknya Kota Terpadu Mandiri (KTM) membuat geliat perekonomian semakin menunjukan trend yang positif. Akan tetapi peningkatan tarap hidup dan ekonomi ini bila tidak dibarengi dengan kesadaran pendidikan akan menimbulkan kesenjangan.

Terbukanya lapangan pekerjaan yang lebar dan mudahnya akses mendapat pekerjaan merupakan hal yang positif. Idealnya hal tersebut harus dibarengi dengan kesadaran pendidikan yang tinggi, bila tidak dibarengi kesadaran pendidikan maka akan menimbulkan paradigma instan (biar tidak sekolah/kuliah yang penting dapat 
kerja). Sebagian pemuda (anak usia sekolah) memilih untuk bekerja dari pada melanjutkan pendidikan ke jenjang yang lebih tinggi. Pola pikir seperti ini merupakan ancaman yang segera mungkin untuk dikikis (Mubarak, 2018).

Walaupun secara agregat, pendidikan masyarakat di Desa Huwongo Paguyaman mengalami peningkatan, baik kuantitas ataupun kualitas, tetapi paradigma instan seperti di atas masih ada yang melekat pada sebagian masyarakat di daerah Transmigran di Desa Huwongo Paguyaman. Hal yang menarik untuk diketahui dari kondisi tersebut adalah bagaimana peranan keluarga sebagai pranata sosial yang pertama dalam menanamkan pendidikan kepada anak-anaknya, dan bagaimana pendidikan anak dalam keluarga tersebut.

\section{Metode}

Penelitian ini dilakukan di Desa Huwongo Paguyaman, Kabupaten Boalemo Provinsi Gorontalo. Penelitian ini menggunakan pendekatan kualitatif, sedangkan data yang diperoleh bersumber dari masyarakat Transmigran di Desa Huwongo.

Dalam penelitian ini pengambilan data dilakukan secara langsung di lapangan dengan teknik pengumpulan data yang menggunakan teknik Participant Observation, intreview dan dokumentasi.Teknik pengumpulan data yang digunakan dalam penelitian ini adalah observasi, wawancara dan dokumentasi. Dari teknik pengumpulan data tersebut, penjelasannya dideskripsikan sebagai berikut:

Metode observasi ini digunakan untuk menggali data tentang Pendidikan Anak Pada Masyarakat Muslim Transmigran Di Desa Huwongo Provinsi Gorontalo.

Metode interview ini untuk mendapatkan data dari seluruh informan tentang berbagai masalah penelitian yang berkaitan dengan Pendidikan Anak Pada Masyarakat Muslim Transmigran Di Desa Huwongo.

Peneliti menggunakan metode dokumentasi ini untuk mengetahui data yang berupa dokumen tertulis atau tercetak, daftar, catatan, opini, komentar, dan sumber lain yang relevan, tentang manajemen mutu pendidikan Islam, visi misi, keadaan Masyarakat Muslim Transmigran Di Desa Huwongo. 


\section{Hasil}

Pelaksanaan Pendidikan Anak pada Masyarakat Muslim Transmigran di Desa Huwongo Paguyaman Kabupaten Boalemo

Pada umumnya berbagai bentuk pelaksanaan pendidikan telah nampak pada masyarakat Transmigran di Desa Huwongo ini. Hal ini bisa dibuktikan dengan tidak seorang anakpun dari masyarakat Transmigran ini yang tidak mengenyam pendidikan. Hal ini disebabkan oleh dorongan dan kemauan orang tua itu sendiri karena bagi mereka apapun keadaannya anak-anak tetap wajib belajar terutama di sekolah formal, seperti yang telah dikemukakan oleh salah seorang pembina UPT, ibu Santun Huntoyungo dalam wawancara :

Masalah orang tua sangat antusias dan sangat memperdulikan masalah pendidikan formal anak-anak mereka. Ini terbukti dengan adanya kenyataan yang ada bahwa semua anak-anak dari masyarakat Transmigran mengenyam pendidikan formal baik dari SD, SMP, sampai SMA sederajat (Huntoyungo, 2020).

Walaupun dalam kenyataan bahwa khususnya di lokasi Transmigran belum ada sekolah yang formal itu bukanlah penghalang anak-anak dan orang tua untuk melanjutkan sekolah, seperti yang dikemukakan ibu santun bahwa,

Walaupun belum ada sekolah formal khusus masyarakat Transmigran akan tetapi itu tidak menyulut niat orang tua untuk menyekolahkan anak-anak mereka, bahkan SMP dan SMA itu sangat jauh dari tempat tinggal akan tetapi bukan jadi penghalang untuk melanjutkan anak-anak mereka dalam sekolah formal (Huntoyungo, 2020).

Dan menurut pengamatan penulis bahwa memang benar yang dikatakan oleh ibu Santun tersebut bahwa khususnya di lokasi Transmigran ini belum ada sekolah formal, yang terdekat dengan lokasi hanyalah sekolah SD 26 Paguyaman, sedangkan SMP, SMA, dan SMK sederajat itu sangat jauh dari lokasi yang ada di desa tetangga atau di pusat kabupaten. Akan tetapi hal ini bukan karena kurangnya perhatian dari pemerintah sebab upaya pemerintah untuk membangun sekolah formal khususnya untuk masyarakat Transmigran ini sudah mulai nampak yaitu dengan mulai dibangunnya 1 unit Sekolah Dasar yang rencananya sudah mulai beroperasi tahun 2018 ini, seperti yang dikatakan oleh kepala desa Huwongo Bapak Samsana Bano, 
Kondisi pendidikan formal anak masyarakat Transmigran desa Huwongo ini sebenarnya sangat baik. Adapun sarana dan prasarana sekolah formal di daerah Transmigran desa Huwongo sebenarnya tersandung dengan keadaan sekolah formal itu sendiri, di wilayah masyarakat Transmigran desa Huwongo belum ada sekolah formal yang khusus masyarakat Transmigran, selama ini anak-anak masyarakat Transmigran desa Huwongo masih sekolah di sekolah - sekolah formal terdekat, misalnya SDN 26 Paguyaman yang masih tergolong jauh dari lokasi, apalagi SMP dan SMA yang sangat jauh dari rumah. Namun hal ini bukan menjadi kendala untuk sekolah (Bano, 2020).

Namun dari pihak pemerintah kabupaten sudah merencanakan pembangunan sekolah formal, seperti yang dikemukakan oleh bapak Samsana Bano dalam waktu dekat ini pemerintah telah berusaha membangun sekolah formal di wilayah masyarakat Transmigran desa Huwongo, hal ini telah diawali dengan pembangunan Sekolah Dasar yang insya Allah sudah mulai beroperasi tahun 2018 ini. Dan rencana juga sekolah tersebut akan dilanjutkan pembangunannya menjadi SMP satu atap.

Selain apa yang sudah dikemukakan di atas ada lagi yang bisa membuktikan bahwa di sekolah formal anak-anak masyarakat Transmigran sangat baik yaitu tentang prestasi mereka di sekolah dibanding dengan anak-anak lokal, seperti yang telah dikemukakan oleh salah seorang warga Transmigran lokal mengatakan bahwa:

Mengenai prestasi anak - anak masyarakat Transmigran desa Huwongo sangat baik sekali, ini terlihat dari prestasi di setiap penyerahan raport di tiap semester di sekolah selalu yang menjadi unggul prestasi siswa adalah anak-anak dari masyarakat Transmigran desa Huwongo dibandingkan dengan anak-anak masyarakat lokal, ini karena dorongan dan motivasi dari orang tua masing masing masyarakat Transmigran desa Huwongo (Tute, 2020).

Oleh karena itu dapat disimpulkan bahwa pendidikan formal anak di masyarakat Transmigran ini tidak diragukan lagi kualitas dan kuwantitasnya karena adanya antusias dari orang tua itu sendiri yang begitu tinggi, sebab apapun kekurangan dan kelebihan fasilitas yang disediakan oleh pemerintah tanpa ada dorongan dari orang tua siswa tentu semua itu tidak ada artinya.

\section{Pembahasan}

Adapun gambaran pelaksanaan pendidikan anak pada masyarakat muslim transmigran di Desa Huwongo dapat diklasifikasikan sebagai berikut: 


\section{Menampilkan Suri Tauladan yang Baik (Uswah)}

Anak mempunyai kepekaan dan rasa ingin tahu yang sangat besar dan kebiasaan anak adalah suka meniru prilaku orang tua dan orang di sekitarnya, suasana lingkungan dan rumah adalah cermin bagaimana bentuk dan perilaku anak kelak. Karenanya orang tua harus menjadi contoh dalam membiasakan anak dengan kebiasaan yang baik sangat diperlukan (Mahmud \& Dkk, 2013).

Etos kerja orang tua yang tinggi dan keuletannya, nampaknya menurun pada anak-anak mereka. Idealnya hal tersebut terbawa pada keuletan dan etos kerja yang tinggi untuk memperbaiki kualitas diri terutama dengan pendidikan. Perlu digaris bawahi bahwa seorang anak tidak hanya harus mendapatkan pendidikan yang setinggi-tingginya. Akan tetapi orang tua harus menanamkan nilai-nilai moral sebagai acuan utama dalam kontrol diri anak.

Penempatan nilai-nilai moral sebagai acuan utama bagi anak agar memiliki kontrol diri secara internal agar senantiasa merujukkan diri anak pada nilai-nilai moral. Sehubungan dengan itu, upaya orang tua dalam mendisiplinkan diri anak pada dasarnya mengupayakan pada anak-anaknya untuk berperilaku yang sadar akan nilai-nilai moral. Nilai-nilai agama juga sangat besar pengaruhnya terhadap keberhasilan keluarga. Keluarga yang berakar pada ketaatan, perilaku-perilaku anggota keluarganya akan senantiasa dikendalikan oleh keyakinan terhadap agamanya (Salim, 2018).

Dalam konteks ini, upaya orang tua untuk menumbuhkan kontrol diri anak yang didasari nilai-nilai moral agama seyogianya terartikulasikan di dalam nilai-nilai moral lainnya seperti; nilai sosial, ekonomi, belajar, demokrasi, kebersihan dan keteraturan. Dengan kata lain, semua nilai moral tersebut sedapat mungkin merupakan cerminan dari nilai-nilai agama karena memberikan arah yang jelas kepada anak dan mencerminkan disiplin diri yang bernuansa agamis (Tola et al., 2020). Hal semacam inilah yang seharusnya diperhatikan oleh para orang tua di Desa Huwongo. Karena selama ini aktualisasi nilai-nilai moral semacam ini tidak menjadi perhatian oleh sebagian masyarakat sehingga mengakibatkan kurang terkontrolnya perilaku anak. Hal ini terbukti bahwa sebagian masyarakat transmigran khususnya di Desa Huwongo sangat kurang memperhatikan terhadap pendidikan agama bagi anak-anak.

Keteladanan keluarga dalam pendidikan anak merupakan bagian dari sejumlah metode ampuh dan efektif dalam mempersiapkan dan membentuk secara 
moral, spiritual, dan sosial. Sebab orang tua merupakan contoh ideal dalam pandangan anak sehingga segala tindakannya akan berpengaruh kepada kepribadian anak. Bahkan disadari atau tidak semua keteladanan itu akan melekat baik dalam bentuk ucapan, perbuatan, hal yang bersifat material, inderawi, maupun spiritual. Meskipun anak berpotensi besar untuk meraih sifat-sifat baik dan menerima dasar-dasar pendidikan yang mulia, ia akan jauh dari kenyataan positif dan terpuji jika ia melihat langsung tindakan negatif yang dilakukan oleh orang tuanya (Rusydi, 2013).

Keteladanan adalah perkataan yang tercermin dalam tindakan atau sebaliknya. Dalam memberikan keteladanan, orang tua seharusnya melakukan secara konsisten, karena konsistensi akan membuat keteladanan melekat dalam diri anak. Dalam beberapa hal banyak sekali orang tua yang menginginkan anakanaknya menjadi anak yang shalih tetapi di sisi lain mereka tidak konsisten dengan keteladanan tersebut. Hal demikian yang sering nampak pada masyarakat Transmigran di Desa Huwongo.

Keteladanan dalam pendidikan merupakan bagian dari sejumlah metode paling ampuh dan efektif dalam mempersiapkan dan membentuk anak-anak secara moral, spiritual, dan sosial. Seorang pendidik merupakan contoh ideal dalam pandangan anak, tingkah laku dan sopan santunnya akan ditiru, disadari atau tidak bahkan semua keteladanannya akan melekat pada diri dan perasaanya.

Gambaran sikap orang tua sebagaimana hasil temuan peneliti menunjukkan betapa minimnya keteladanan dan perhatian orang tua terhadap anak dalam hal pendidikan agama. Sehingga peneliti menyimpulkan bahwa penduduk Desa Huwongo kurang memberikan keteladan terhadap nilai-nilai agama, akan tetapi yang mereka teladankan adalah nilai-nilai kegigihan dan keuletan dalam etos kerja dan mencari materi. Disamping memberikan tauladan, orang tua juga berkewajiban membiasakan anak untuk selalu melakukan sesuatu yang positif. Pembiasaan kepada anak dilakukan untuk melatih kedisiplinan anak, sehingga ketika anak dewasa telah terbiasa dan mendarah daging.

\section{Melatih dan Membiasakan Hal-hal yang Baik (Pembiasaan)}

Keluarga merupakan lembaga pendidikan tertua yang bersifat informal, dalam keluargalah anak mendapatkan pendidikan yang pertama dan utama. Dikatakan pendidikan pertama karena dalam keluarga inilah anak pertama-tama mendapat pendidikan dan bimbingan. Juga dikatakan pendidikan yang utama 
karena sebagian besar hidup dan kehidupan anak berada dalam keluarga. Keluarga juga merupakan lembaga pendidikan yang bersifat kodrati, di mana orang tua bertanggung jawab memelihara, merawat, melindungi dan mendidik anak agar tumbuh dan berkembang dengan baik. Secara sederhana keluarga diartikan sebagai kesatuan hidup bersama yang pertama dikenal oleh anak (Tola et al., 2020).

Pendidikan agama masyarakat muslim transmigran di Desa Huwongo pada umumnya dipusatkan di mushola atau masjid, sebagai pengajar adalah orang 'Alim (orang yang dianggap paling berilmu) sebagai pemangku mushola setempat. Diajarkan kepada anak-anak beberapa ilmu agama seperti membaca al-Qur'an beserta tajwidnya, aqoid dan fikih.

Sesuai pengamatan peneliti ternyata di Desa Huwongo sangat minim sekali anak yang telah bersekolah di jenjang SMP/MTs kemudian mengaji di musholla, bahkan tidak ada lagi siswa sekolah tingkat SMA/ MA yang mengaji di masjid atau musholla. Sebagaian besar yang mengaji di masjid adalah anak-anak yang masih sekolah di tingkat dasar (SD). Alasan mereka tidak mau mengaji di masjid karena malu merasa dirinya sudah besar.

Kondisi seperti ini sebenarnya tidak perlu terjadi seandainya orang tua mampu menanamkan kecintaan terhadap ilmu kepada anak-anaknya. Tugas orang tua dan guru adalah membimbing anak agar mencintai ilmu, sehingga dengan kecintaanya terhadap ilmu dengan sendirinya mereka akan semangat belajar. Orang tua hendaknya tidak merasa cukup hanya sekedar menunaikan tanggung jawabnya, mengira bahwa dirinya telah bersungguh-sungguh, sehingga ia telah terlepas dari dosa. Seorang pendidik yang sadar dan bertanggung jawab akan selalu berusaha mencari metode yang lebih efektif dan mencari pedoman-pedoman pendidikan yang lebih baik dalam rangka mempersiapkan anak-anaknya sehingga mencapai kesempurnaan, kedewasaan, dan kematangan berfikir.

\section{Mengarahkan dan Menasehati untuk Selalu Melakukan Hal-hal yang Positif (Pengarahan dan Nasehat)}

Setelah membiasakan anak untuk disiplin, hal yang tidak kalah pentingnya dalam mendidik anak adalah dengan mengarahkan. Pengarahan bertujuan menunjukan jalan terbaik untuk anak, karena anak belum matang akalnya dalam menentukan yang baik dan buruk. Sehingga mutlak pengarahan diperlukan dalam pendidikan anak. Pengarahan juga dalam rangka menjaga kebiasaan-kebiasaan yang baik sehingga tetap terjaga (A. M. D. Pawero, 2021). 
Masyarakat Desa Huwongo sebagaimana peneliti katakan adalah masyarakat dengan etos kerja yang tinggi serta ulet. Sayangnya hal tersebut tidak dibarengi dengan perhatiannya kepada anak agar mereka terus mendapatkan pendidikan non formal ini, walaupun sebenarnya sang anak sudah mendapatkan pendidikan umum (SD, SMP, SMA) dan sederajat. Akan tetapi dalam hal pendidikan agama yang sebenarnya sudah tersedia baik tempat maupun waktunya, kebanyakan orang tua kurang memperhatikan dan kurang memberikan dorongan kepada anak sehingga sang anak pun enggan untuk belajar ilmu agama dengan berbagai alasan.

Hal semacam inilah yang seharusnya segera disadari oleh para orang tua dalam kaitannya dengan pendidikan terhadap anak-anak terutama masalah pendidikan agama (Afrida, 2012). Karena tanpa perhatian dan dorongan orang tua, seorang anak akan menganggap tidak penting untuk belajar ilmu agama setelah ia sekolah di pendidikan umum. Sebagaimana pengakuan dari salah seorang anak saat diminta keterangan mengenai pendidikan di luar sekolah dengan mengatakan bahwa ia tidak mau lagi belajar setelah ia pulang sekolah dengan alasan capek.

Dengan rutinitas keseharian yang hampir seluruh waktu dihabiskan untuk bekerja berimplikasi terhadap semakin minimnya waktu bersama anak-anak, dalam aktifitas pertanian, ibu rumah tangga banyak membantu dalam menyelesaikan pekerjaan-pekerjaan pertanian dan memegang peranan penting. Pekerjaan menanam padi, menyiangi gulma, memotong padi dan merontok padi, pekerjaanpekerjaan tersebut ibu rumah tangga banyak berperan di dalamnya. Sehingga peran orang tua sebagai pendamping, dan pengawas terhadap aktivitas anak tidak berjalan dengan baik. Di samping itu terbengkalainya salat lima waktu, memperendah nilai orang tua sebagai sentral pendidik dalam keluarga, terutama fungsinya sebagai suri tauladan yang seharusnya memberi contoh pengamalan agama yang baik.

Di antara faktor-faktor yang berpengaruh terhadap proses pembentukan sikap ilmiah, ruhaniah, dan jasmaniah anak ialah adanya kerjasama yang erat antara rumah, sekolah dan masjid. Sebagaimana diketahui bersama bahwa tanggung jawab rumah tangga menduduki urutan pertama dalam hal pendidikan. Banyaknya orang tua dan guru yang tidak memahami pentingnya pendidikan yang baik dan seimbang. Dalam mewujudkan pendidikan yang efektif dan seimbang kerjasama antara rumah, sekolah dan masjid harus sejalan dan searah sehingga tidak menimbulkan kebimbangan terhadap anak, sehingga akan menjadi penghambat tercapainya pendidikan yang baik (Mahmud \& Dkk, 2013). 
Beberapa keluarga yang peneliti amati dan perhatikan merupakan keluarga petani yang sangat rajin dan ulet, terutama para pria mereka berangkat ke sawah pagi-pagi sekali dan pulangnya setelah petang. Rutinitas seperti ini hampir dilakukan setiap hari. Sedangkan para wanita biasanya berangkat ke sawah setelah menyelesaikan pekerjaan rumah, seperti memasak, mencuci, menyapu dan sebagainya. Lazimnya para wanita berangkat ke sawah membawa kiriman berupa makanan sebagai bekal bekerja di sawah selama sehari. Setelah seharian bekerja keras di sawah, tidak heran bila mereka kelelahan sehingga waktu malam merupakan waktu yang paling nyaman. Badan yang capek dan lelah setelah bekerja keras seharian membuat mereka memilih untuk beristirahat lebih awal. Jadi tidak heran bila desa sudah terasa sunyi walaupun waktu masih menunjukkan pukul 20.00 malam.

Alat transportasi, terutama motor saat ini bisa dikatakan kebutuhan primer oleh masyarakat transmigran dalam rangka menunjang efektifitas kerja. Kalau dilihat secara kasat mata, kesannya persaingan atau berlomba menunjukkan kekayaan. Akan tetapi bila dicermati secara mendalam memang motor saat ini merupakan alat utama bagi masyarakat karena mengingat jarak tempuh antara satu tempat ke tempat lain sangat jauh. Akan tetapi, salah satu dampak negatif dengan adanya motor adalah seringnya anak terutama anak laki-laki keluar malam dan menghabiskan waktu sia-sia. Di samping motor, handphone juga sangat berpengaruh terhadap aktifitas keseharian anak. Kecenderungan yang kurang baik lainnya adalah mudahnya orang tua menuruti kemauan anak tanpa mempertimbangkan manfaat dan tanpa menyaring dampak negatifnya. Salah satu yang marak adalah penggunaan telephone celuler, peneliti menilai pemberian telephone celuler kepada anak bukan berdasarkan nilai manfaatnya, melainkan karena pertimbangan gengsi semata.

Melihat dari kenyataan di atas, maka tidak dapat dipungkiri bahwa salah satu pemicu dari malasnya anak-anak untuk belajar agama di masjid adalah karena pengaruh alat transportasi berupa motor yang dimanfaatkan oleh anak-anak untuk keluar malam sehingga mereka tidak lagi memperdulikan tentang pendidikan agama. Selain dari itu pengaruh kemalasan dikarenakan alat komunikasi berupa hand phone, karena hand phone bagi masyarakat Desa Huwongo adalah suatu yang baru karena memang keberadaan hand phone di daerah tersebut masih tergolong baru sehingga tidak heran kalau mereka masih banyak yang terlena dengan keberadaannya. Dengan kondisi ini orang tua dituntut untuk lebih memperhatikan 
anaknya, dan salah satu yang dianjurkan adalah pengarahan dan nasehat. Pengarahan bertujuan menunjukan jalan terbaik untuk anak, pengarahan juga dalam rangka menjaga kebiasaan-kebiasaan yang baik sehingga tetap terjaga. Sedangkan nasihat bertujuan meluruskan perbuatan anak yang menyimpang. Dengan nasehat yang baik dan santun tanpa menghakimi kesalahan anak, akan lebih membekas dalam benak anak sehingga anak akan meninggalkan kesalahannya dengan kesadarannya sendiri.

Manusia diciptakan dengan potensi mampu berbuat baik dan berbuat jahat. Jika ia hidup dengan pendidikan dan lingkungan yang baik, kemungkinan besar ia akan tumbuh berkembang dan menjadi orang baik. Adapun sistem Islam dalam memperbaiki anak adalah bersandarkan dua dasar pokok yaitu: pemberian contoh yang baik, pengajaran, dan pembiasaan (Ismail Suwardi Wekke, 2018). Periode anak hendaknya lebih banyak mendapatkan pengajaran dan pembiasaan ketimbang pada usia dan periode lainnya. Suatu keniscayaan bagi para pendidik dan orang tua adalah menekankan pengajaran dan pembiasaan anak sejak dini untuk melakukan kebaikan.

Di antara faktor-faktor yang berpengaruh terhadap proses pembentukan ilmiah, rohaniah, dan jasmaniah anak ialah adanya kerjasama erat antara rumah, sekolah, dan masjid. Sebagaimana dimaklumi, tanggung jawab rumah tangga menduduki urutan pertama dalam hal pendidikan jasmani. Berdosa besar bagi orang tua yang menyia-nyiakan kewajibannya terhadap anak-anaknya.

Ketika dipandang bahwa ketiga unsur yakni rumah, sekolah, dan masjid saling membantu berarti dengan demikian kepribadian anak, rohani, jasmani, akal dan jiwanya akan lebih matang. Bahkan ia akan menjadi salah seorang anggota masyarakat yang menjadi pelopor kemajuan umat dan agamanya. Namun demikian saling membantu dan kerjasama ini tidak akan berjalan sempurna kecuali dengan adanya dua syarat pokok yaitu; Pertama, hendaknya antara pengarahan rumah dan sekolah itu tidak bertentangan. Kedua, hendaknya saling membantu dan kerjasama itu bertujuan untuk menegakkan penyempurnaan dan keseimbangan dalam upaya membina pribadi yang Islami. Jika kerjasama ini memenuhi syarat tersebut, kemungkinan besar rohani, jasmani, dan fisik anak akan menjadi sempurna di samping akan menjadi insan yang berkeseimbangan juga akan mengundang kekaguman banyak orang. 
Jadi dari uraian di atas, dapat diketahui bahwa orang tua di rumah merupakan penanggung jawab utama di bidang pendidikan fisik dan moral anak. Masjid sebagai media pendidikan ruhani, sementara sekolah sebagai pembentukan akidah, ilmu dan budaya.

\section{Simpulan}

Berdasarkan hasil penelitian sebagaimana di paparkan di atas, penelitian ini dapat disimpulkan sebagai berikut:

1. Terdapat empat prinsip yang dimiliki oleh keluarga Muslim Transmigran di Desa Huntoyungo Paguyaman, Kabupaten Boalemo Provinsi Gorontalo dalam pendidikan anak yaitu, a) Menampilkan Suri Tauladan yang Baik (Uswah). Hal ini dapat dilihat dari etos kerja orang tua yang tinggi dan keuletan orang tua yang menurun pada anak-anak mereka. b) Melatih dan Membiasakan Hal-hal yang Baik (Pembiasaan). Hal ini dapat dilihat dari upaya orang tua untuk terus membiasakan anak-anaknya belajar di musholla, dengan pengajar 'Alim (orang yang dianggap paling berilmu) sebagai pemangku mushola setempat yang mengajarkan kepada anak-anak beberapa ilmu agama seperti membaca al-Qur'an beserta tajwidnya, aqoid dan fikih. c) Mengarahkan dan Menasehati untuk Selalu Melakukan Hal-hal yang Positif (Pengarahan dan Nasehat).

2. Adapun tantangan yang dihadapi Masyarakat Muslim Imigran dalam pendidikan anak adalah pengaruh alat transportasi berupa motor yang dimanfaatkan oleh anak-anak untuk keluar malam sehingga mereka tidak lagi memperdulikan tentang pendidikan agama. Selain dari itu pengaruh kemalasan dikarenakan alat komunikasi berupa handphone, karena handphone bagi masyarakat Desa Huwongo adalah suatu yang baru karena memang keberadaan handphone di daerah tersebut masih tergolong baru sehingga para orang tua sering kesulitan untuk mengatasi problem kecanduan handphone kepada anak-anak mereka

\section{Referensi}

Afrida. (2012). Peran Guru Pendidikan Agama Islam dalam Meningkatkan Prestasi Belajar Siswa tentang Pelajaran Agama di SD Limus Nunggal 02 Cileungsi. FITK UIN Jakarta. 
Bano, S. (2020). Wawancara dengan Kepala Desa Huwongo di Kantor Desa Huwongo.

Daeng Pawero, A. M. V. (2018). Analisis Kritis Kebijakan Kurikulum Antara KBK, KTSP, dan K-13. Jurnal Ilmiah Iqra', 12(1), 42. https://doi.org/10.30984/jii.v12i1.889

Daradjat, Z. (2018). Pendidikan Islam dalam Keluarga dan Sekolah. Remaja Rosda Karya.

Farihah, I., \& Nurani, I. (2017). Internalisasi Nilai-Nilai Keislaman Dalam Skema Hidden Curriculum Di Mts Nurul Huda Medini Demak. Edukasia: Jurnal Penelitian Pendidikan Islam, 12(1), 213-234. https://doi.org/10.21043/EDUKASIA.V12I1.2347

Firmadani, F. (2017). Pembelajaran Berbasis Riset Sebagai Inovasi Pembelajaran. Prosiding TEP \& PDs, 4(14), 262-268.

Huntoyungo, S. (2020). Wawancara dengan Pegawai Dinas Tenaga Kerja dan Transmigran Unit Pemukiman Transmigran SP-6 Desa Huwongo.

Ismail Suwardi Wekke, A. S. Y. S. (2018). PENDIDIKAN KARAKTER DALAM MASYARAKAT BUGIS. Ijtimaiyya: Jurnal Pengembangan Masyarakat Islam. https://doi.org/10.24042/ijpmi.v1111.3415

Kristiawan, M. (2017). Manajemen Pendidikan. Budi Utama.

Mahmud, \& Dkk. (2013). Pendidikan Agama Islam dalam Keluarga. Akademia Permata.

Mubarak, Z. (2018). Pendidikan Di Era Revolusi Industri 4.0 Dan Problematika Pendidikan Tinggi. Ganding Pustaka.

Pawero, A. M. D. (2021). Arah Baru Perencanaan Pendidikan Dan Implikasinya Terhadap Kebijakan Pendidikan. Dirasah: Jurnal Studi Ilmu Dan Manajemen ..., 4(1). http://ejournal.iaifa.ac.id/index.php/dirasah/article/view/177

Pawero, A. M. V. D. (2017). Analisis Kritis Kebijakan Standar Kompetensi Lulusan (SKL) Dan Standar Isi Kurikulum Pendidikan Agama Islam. Journal of Islamic Education Policy, 2(2), 166.

Redaksi Ensiklopedi Nasional. (1990). Ensiklopedi Nasional Indonesia. PT. Cipta Adi Pustaka.

Rusydi, S. (2013). Nilai-Nilai Karakter Islam : Berhulu dari Akhlak, berhilir pada Rahmat. Marja. 
Salim, A. (2018). Pendidikan Karakter Dan Eksistensi Pemuda. Potret Pemikiran. https://doi.org/10.30984/pp.v19i2.728

Sedarmayanti. (2011). Manajemen Sumberdaya Manusia Reformasi Birokrasi dan Manajemen Pegawai Negeri Sipil. Refika Aditama.

Shochib, M. (2001). Pola Asuh Orang Tua dalam Membentuk Anak Mengembangkan Disiplin Diri. Rineka Cipta.

Suparno, E. (2007). Paradigma Transmigrasi Menuju Kemakmuran Rakyat. Departemen Tenaga Kerja dan Transmigrasi Republik Indonesia.

Tola, A., Pawero, A. M. D., \& Tabiman, N. H. (2020). Pengembangan Religious Culture Melalui Manajemen Pembiasaan Diri Berbasis Multikultural. J-MPI (Jurnal Manajemen Pendidikan Islam), 5(2), 147-159.

Tute, I. (2020). Wawancara dengan Warga Transmigran Desa Huwongo.

Yamin, M. (2010). Menggugat Pendidikan Indonesia, Belajar dari Paulo Preire dan Ki Hajar Dewantara. Ar Ruzz Media. 